\title{
Green and brown propolis: efficient natural biocides for the control of bacterial contamination of alcoholic fermentation of distilled beverage
}

\author{
Márcia Justino Rossini MUTTON ${ }^{1 *}$, José Humberto de OLIVEIRA FILHO ${ }^{1}$, Gustavo Henrique Gravatim COSTA ${ }^{1}$, \\ Juliana Pelegrini ROVIERO ${ }^{1}$, Lidyane Aline de FREITA ${ }^{1}$
}

\begin{abstract}
This study aimed to evaluate the efficiency of natural biocides, brown and green propolis, for the control of bacterial contamination in the production of sugarcane spirit. The treatments consisted of brown and green propolis extracts, ampicillin, and a control and were assessed at the beginning and end of harvest season in ten fermentation cycles. In the microbiological analyses, the lactic acid bacteria were quantified in the inoculum before and after the treatment with biocides, and the viability of yeast cells during fermentation was evaluated. The levels of acids, glycerol, total residual reducing sugars, and ethanol were analyzed for the wine resulting from each fermentation cycle. A reduction in the number of bacterial contaminants in the inoculum in the treatments with the natural biocides was observed, but it did not affect the viability of yeast cells. The control of the contaminants led to the production of higher levels of ethanol and reduced acidity in the wine produced. The results of the use of brown and green propolis to control the growth microorganisms in the fermentation of sugarcane spirit can be of great importance for using alternative strategies to synthetic antibacterials in fermentation processes including other distilled beverage or spirits.
\end{abstract}

Keywords: sugarcane spirit; antimicrobials; natural products; lactic acid bacteria; ethanol.

Practical Application: Control of bacterial contamination using organic biomolecules.

\section{Introduction}

A major challenge in the production of spirits is the presence of antibiotic residues, which have recently become a major consumer concern and has been regulated by food and health regulatory agencies throughout the world (Food Standards Agency, 2011). Therefore, efforts have been made in search for alternative organic bactericides that maintain beverage quality while complying with market demand and food and health regulatory agencies' demands.

Alcoholic fermentation is one of the major stages of distilled beverage manufacturing, and yeast is the microorganism responsible for fermentation. In order to develop properly, the yeast requires a substrate with specific levels of sugars, $\mathrm{pH}$, temperature, and nutrients among others (Amorim, 2005). However, bacterial contamination can occur in this process, which can cause secondary fermentation and result in the formation of undesirable products such as acids (Camolez \& Mutton, 2005). Consequently, it can affect the yield of alcohol produced and the producers' economic return (Amorim, 2005).

It is known that bacterial concentrations of $10^{9}$ ColonyForming-Units $\left(\mathrm{CFU} \mathrm{mL} \mathrm{m}^{-1}\right)$ can result in a sharp decrease in the alcoholic yield thus requiring the use of antimicrobial agents together with adequate hygiene practices (Amorim, 2005). Among the common biocides is ampicillin, a synthetic type of penicillin, capable of inducing lysis in bacteria (Kohanski et al.,
2010). However, the continued administration of these antimicrobials can lead to the creation of resistant strains, raise the process cost, and allow the incorporation of residues in the product lowering the beverage quality.

Among the natural biocides that can be considered when searching for solutions to this problem is propolis, a resinous bee product that has an efficient antimicrobial activity against a variety of microrganisms (Sforcin \& Bankova, 2011). The mechanism of action of propolis has been attributed to inhibition of cell division, cell wall destruction, cytoplasm disorganization, alterations in the cytoplasmic membrane, and inhibition of protein systhesis (Takaisi-Kikuni \& Schilcher, 1994). However, there is no literature available on the antimicrobial effects of propolis on fermentation processes during distilled spirits production.

The purpose of this study was to compare the efficiency of natural biocides with that of conventional biocides (ampicillin) that have been used by industries to control bacterial contaminants of alcoholic fermentation. Therefore, the effect of brown and green propolis on the control of bacterial contaminants and on yeast viability as well as the quality of wines intended for the production of sugarcane spirits at the beginning and end of the harvest season were evaluated. 
Sugarcane spirit, distilled from fermented sugarcane must, is the third most consumed beverage in the world. Brazil accounts for the production of approximately 1.2 billion liters (Associação Brasileira de Bebidas, 2014). The results of the use of propolis in the fermentation of sugarcane spirit obtained in this study can be of great importance for the alternative and organic control of contaminants of fermentation processes intended to the production of other distillates.

\section{Material and methods}

The experiment was conducted in parallel to the production of sugarcane spirit in the region of Uberaba, at the beginning (July/August) and end (October/November) of the 2009/2010 harvest season. The sugarcane variety SP 70-1406 was used. It was harvested without previous burning of straw and processed immediately after harvesting. The juice extracted by milling was sifted and sent for must preparation (Amorim, 2005).

\subsection{Antimicrobial preparation}

The active ingredients of brown and green propolis (collected respectively in the municipalities of Guaxupé and Patos de Minas - MG - Brazil) were extracted from a mixture of $25 \mathrm{~g}$ of crushed propolis in $100 \mathrm{~mL}$ of $80 \%$ ethanol (v/v) under stirring in a thermostatic bath at $70^{\circ} \mathrm{C}$ for 30 minutos (Park et al., 1998). The ampicillin solution was prepared by grinding a $500 \mathrm{mg}$ tablet into a fine powder in a mortar, which was diluted in $100 \mathrm{ml}$ of distilled water and autoclaved at $121^{\circ} \mathrm{C}$ for 15 minutes.

The doses were established in preliminary experiments conducted to evaluate bacterial growth inhibition without affecting the yeast viability; $700 \mu \mathrm{l} / \mathrm{L}$ of propolis extracts and ampicillin solution were used.

\subsection{Microorganisms and alcoholic fermentation}

The microorganism used in the fermentation process was Saccharomyces cerevisiae, a commercial pressed yeast, at the concentration of $30 \mathrm{~g}\left(7 \times 10^{8}\right.$ cells $\left./ \mathrm{mL}\right)$ per liter. Batch fermentations were carried out, and the yeast was recovered by decantation in stainless steel conical bottom tanks (total capacity of $4.5 \mathrm{~L}$ ).

The treatments consisted of four different musts: control (without addition of biocides), brown propolis extracts and green propolis, and ampicillin solution. Each treatment included $2.5 \mathrm{~L}$ of must at $14^{\circ}$ Brix divided into two groups $(1.0 \mathrm{~L}$ at the first feeding and $1.5 \mathrm{~L}$ after an interval of 60 minutes).

Ten fermentation cycles of 18-24h were conducted. Every two cycles, the yeast was washed with distilled water and the biocides of each treatment. After the end of the $4^{\text {th }}$ fermentation cycle, $10 \mathrm{~g}$ of inert material and dead cells that were in the bottom of the tank were removed.

Quantification of bacterial contamination in the inoculum was performed before and 1 hour after the treatment with biocides by inoculation into specific MRS solid medium (yeast extract $-5 \mathrm{~g}$, peptone $-10 \mathrm{~g}$, beef extract $-5 \mathrm{~g}$, dextrose $-20 \mathrm{~g}$ dipotassium hydrogen phosphate $-2 \mathrm{~g}$, tween $80-1 \mathrm{~g}$, sodium acetate $-5 \mathrm{~g}$, magnesium sulfate $-0.05 \mathrm{~g}$, and agar $-15 \mathrm{~g}$ per liter of medium, and addition of cycloheximide $-100 \mathrm{mg} / \mathrm{L}$ ) (Silva et al., 2003).

To determine the yeast viability, the number of cells and viable and non-viable sprout cells we quantified using a Neubauer chamber (Silva et al., 2003) at the beginning (30 minutes after the last feeding) and the end of the fermentation cycle (after approximately 24 hours, when the Brix reading was in the range of $1 \leq 1$ hour).

At the end of each cycle, the yeast decanted was recovered for wine separation. The wines were analyzed for glycerol, alcohol content, total acidity, and total residual sugars (Silva et al., 2003).

\subsection{Experimental design and statistical analysis}

For the inoculum microbiological analyses and wine technological analyses, a split-plot factorial design in a completely randomized block with three replications $(4 \times 2 \times 10)$ was used including three biocides (brown propolis extracts, green propolis, and ampicillin) and a control, combining the treatments at the beginning and end of the harvest season in 10 fermentation cycles.

\section{Results and discussion}

The first step was to evaluate the raw material for the levels of acidity and lactic acid bacteria contaminants. Raw material quality impairment (relationship between total acidity and lactic acid bacteria) was observed in both period of times studied, but this effect was more pronounced at the end of the harvest season (Figure 1). The data confirm the need for antimicrobial agents to control such contaminants in order to reduce competition with the yeast for the substrate.

These findings are similar to those found in the literature (Mao et al., 2006; Bhatia et al., 2009). Although the results are similar, this is considered preliminary information on the use of sugarcane in an organic production system of sugarcane spirit. This fact may be related to increased temperature and humidity in the plant growth environment since sugarcane harvest season

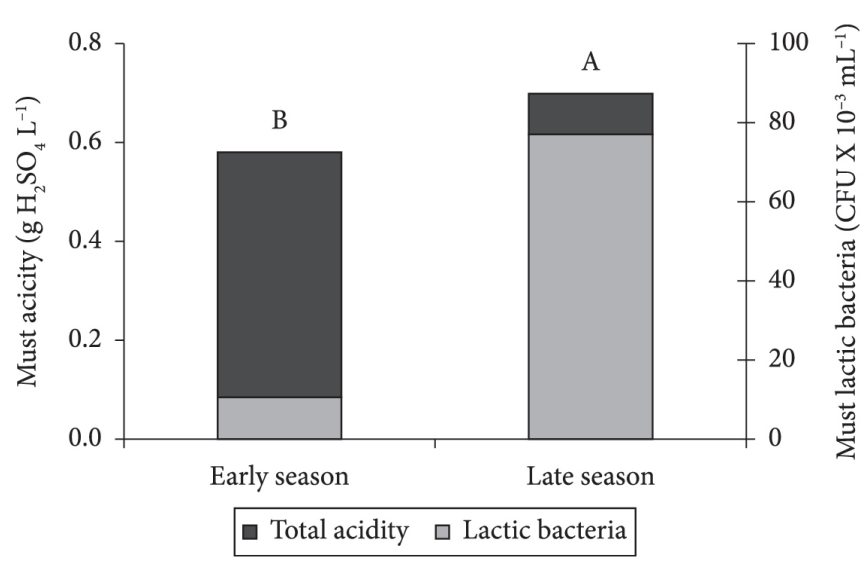

Figure 1. Must total acidity and lactic bacteria mean values at early and late sugarcane harvest seasons. CFU: Colony Forming Unit. 
begins during cold and dry periods and progresses towards hot and rainy periods, thus providing more favorable conditions for the development of bacterial contamination in the raw material (Lavanholi, 2008). Furthermore, the increased water availability and high temperatures increase vegetative growth, thereby increasing the production of organic acids (Celestine-Myrtill, 1990) and a possible aggregation of the acidic compounds formed due to the higher concentrations of contaminating microorganisms at the end of the harvest season.

Next, the effect of the antimicrobial agents on the number of lactic bacteria present in the inoculum at the beginning and end of the harvest season was evaluated. As expected, there were higher concentrations of contaminants in the control experiment (in the absence of antimicrobials), whereas the use of propolis extracts and ampicillin inhibited the growth of lactic acid bacteria in the two different season periods studied (Figure 2) and during the fermentation cycles (Figure 3). In the

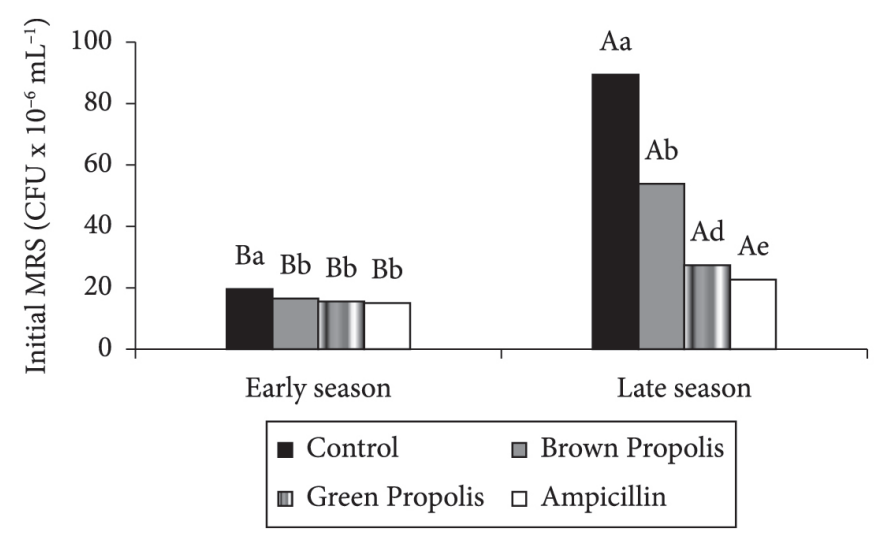

Figure 2. Interaction between treatments and seasons as a function of the presence of lactic bacteria in the inoculum. Capital letters compare means between periods in the same treatment. Lowercase letters compare means between treatments in the same season. control experiment, the highest level of microorganisms was observed at the end of the harvest season (Figure 2), and there was a progressive growth in the number of microorganisms during the cycles, but the difference between the second and the tenth cycle was significant (Figure 3).

Although the effective action of these products has already been demonstrated (Burdock, 1998; Sforcin \& Bankova, 2011; Afrouzan et al., 2012), this is the first report on fermentation process control. The identification of the components responsible for the effects of natural antibacterial compounds used was not the objective of this study. However, it can be said that the antibacterial mechanism of brown and green propolis may be related mainly to phenolic compounds, flavonoids, and terpenes, the major components of this resin (Isla et al., 2005; Sobocanec et al., 2006; Loureiro \& Galbiati, 2013). Nevertheless, these molecules alone do not characterize propolis in terms of its antimicrobial activity, which actually depends on the region where it was produced (Silva et al., 2006; Cabral et al., 2012), the production period, geographic region, and type of material collected by bees substantially affect the concentration of bioactive compounds (Miguel et al., 2014). Further studies are needed to confirm this assumption by identifying the components responsible for the antimicrobial activity in the control of the fermentation process.

Since the viability of yeast cells depends on the microbial activity and on the acidity resulting from the activity of these microorganisms, the next step was to evaluate the activity of antimicrobial agents by quantifying the yeast at the beginning and end of fermentation. When there was no antimicrobial agents (control treatment), a marked reduction in the viability of yeast cells in 10 cycles was observed (Figure 4 ). However, the use of propolis extracts (green and brown) maintained yeast viability, with growth rates above $90 \%$. These results are similar that found by Montijo et al. (2014) with observed reduce of cell viability in 10 cycles of fermentation for control treatment.

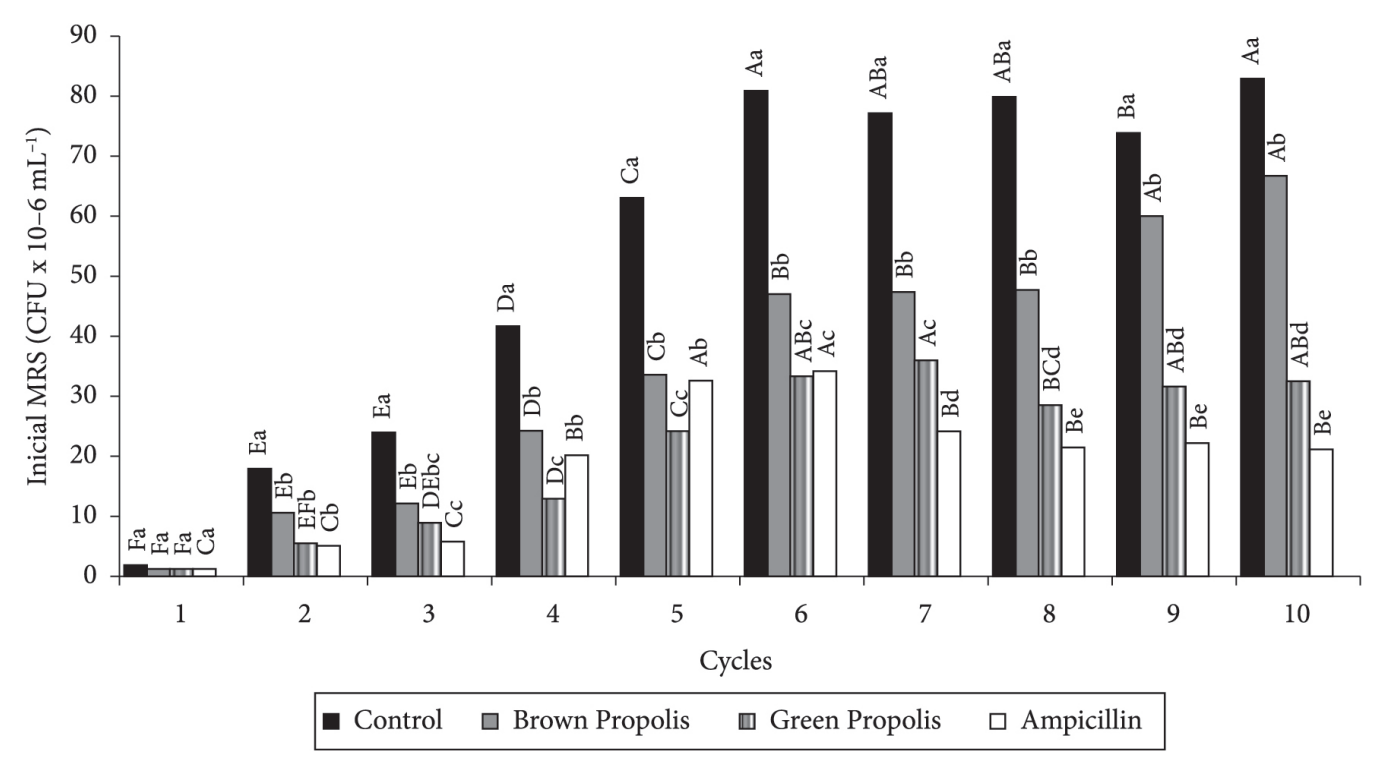

Figure 3. Interaction between treatments and cycles as a function of the presence of lactic bacteria in the inoculum. Capital letters compare means between cycles in the same treatment. Lowercase letters compare means between treatments in the same cycle. 


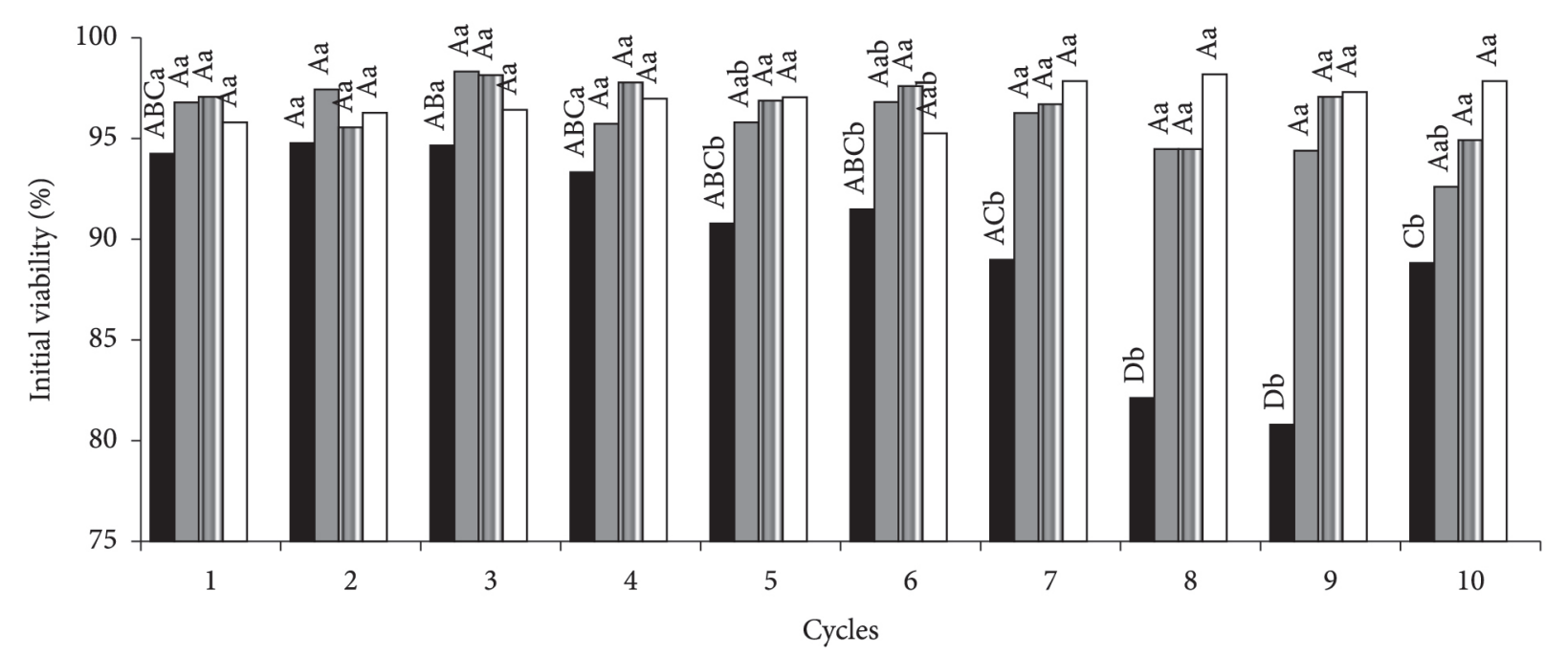

Control $\square$ Brown Propolis $\square$ Green Propolis $\square$ Ampicillin

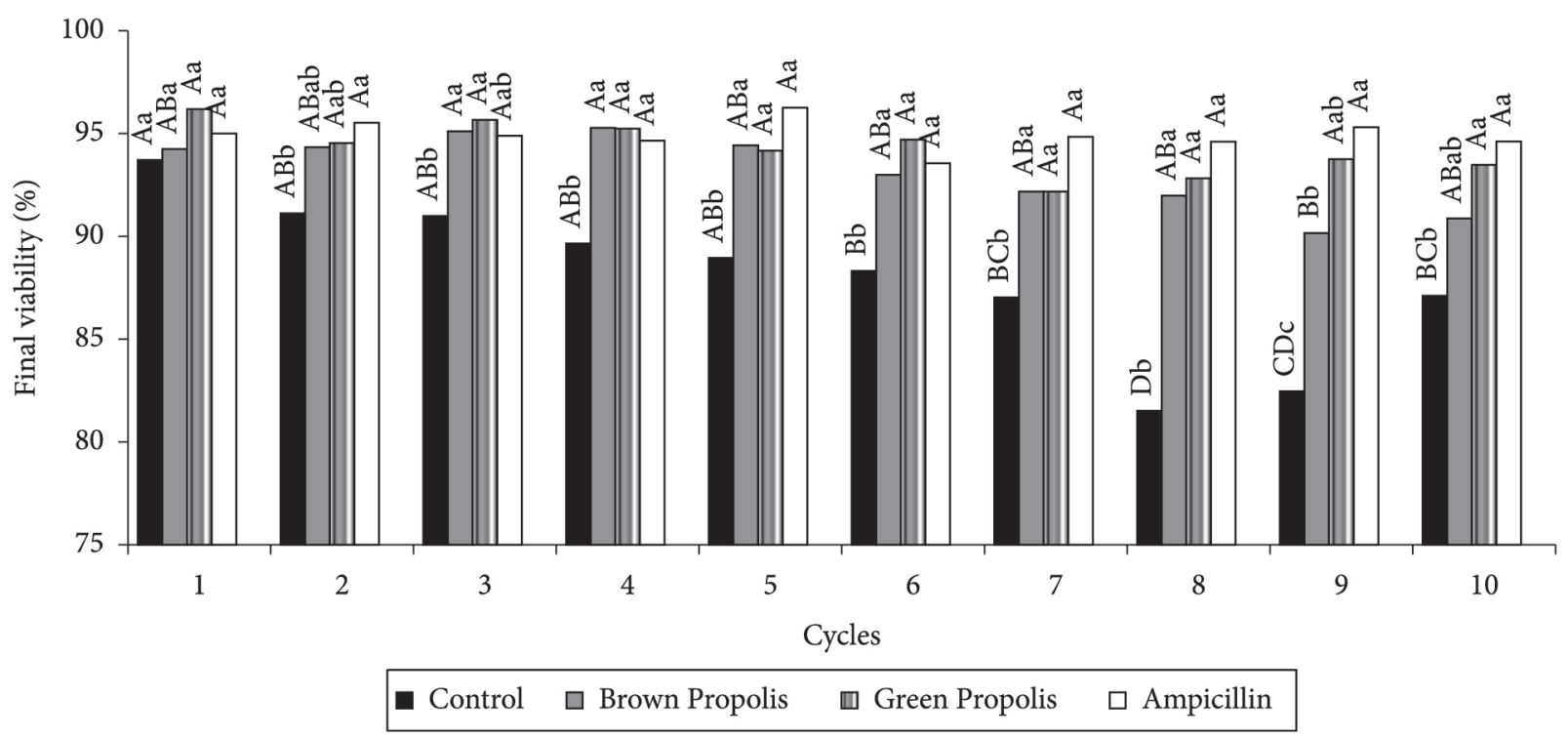

Figure 4. Interaction between treatment and cycles to promote yeast cellular viability at the beginning and end of the fermentation process. Capital letters compare means between 10 cycles in the same treatment. Lowercase letters compare means between treatments in the same cycle. Initial viability $\sigma=3.5841$. Final viability $\sigma=3.3521$.

The use of biocides maintained yeast viability at the beginning and end of the process and throughout the 10 fermentation cycles. These results are in agreement with those reported by Cigut et al. (2011), who also did not observe a negative effect of propolis on the number of live S. cerevisiae cells when compared to that of the treatment without addition of antioxidants. The reduction in the levels of lactic acid bacteria and the consequent decreased acid production and other inhibiting compounds are likely explanations for the better yeast viability observed. Cell viability is the major stress indicator in yeasts, and the higher the percentage of living cells, the better the fermentation performance (Basso et al., 2011). These results demonstrate the ability of propolis to increase substrate competitiveness favoring the maintenance of viable yeast cells during the fermentation cycles.
After fermentation, the total acid content of the wine produced was quantified since it results from the metabolism of contaminant bacteria (Basso et al., 2011). Due to the increase in the microorganisms in the inoculum, there was higher production of acids after the fourth fermentation cycle, and that treatment without antimicrobial addition showed the highest mean values, followed by brown propolis, green propolis, and ampicillin (Figure 5). It should be emphasized that the amount of acid produced by the microorganisms subjected to the action of green propolis and ampicillin was the same in all cycles.

These compounds result from the metabolism of the contaminating microorganisms of fermentation (Wu et al., 2010) and were probably controlled by the addition of biocides. These results corroborate the findings of Camolez \& Mutton (2005), who reported an increase in acidity in fermented 


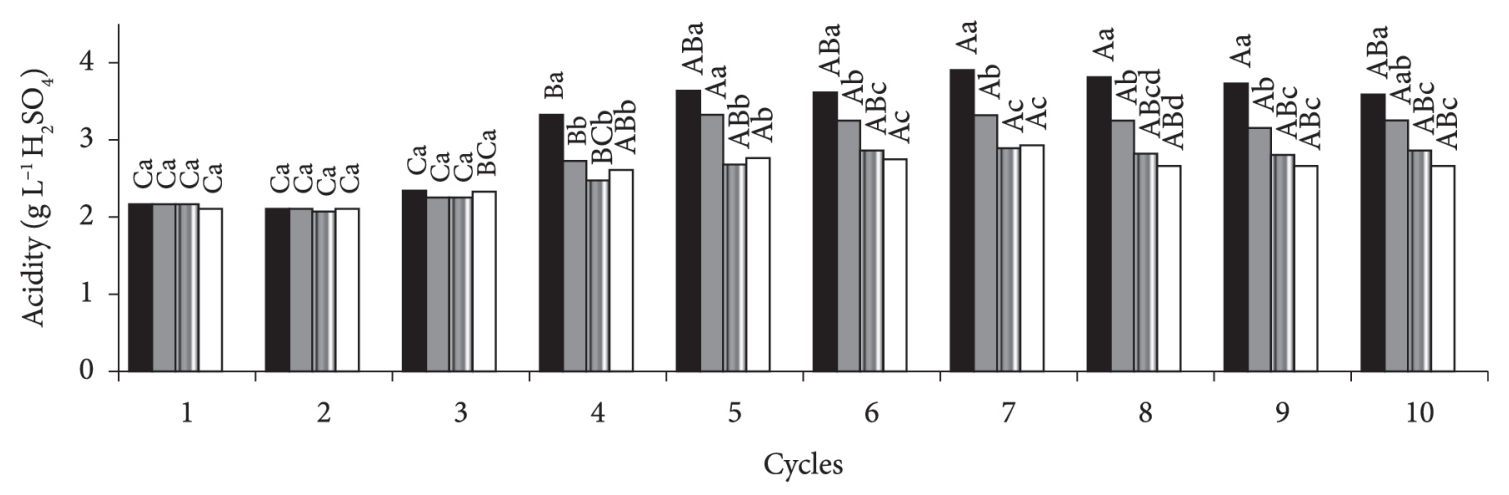

Control $\square$ Brown Propolis $\quad \square$ Green Propolis $\quad \square$ Ampicillin

Figure 5. Interaction between treatments and cycles to measure wine total acidity. Capital letters compare means between cycles in the same treatment. Lowercase letters compare means between treatments in the same cycle.

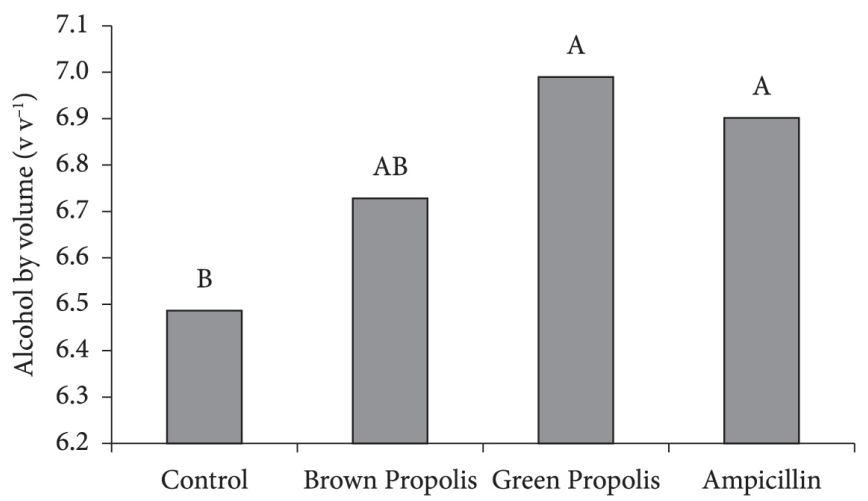

Figure 6. Wine Alcohol Mean values for the treatments with biocide. (2009/2010 harvest season). Capital letters compare means between cycles in the same treatment.

sugarcane must due to an increased number of bacteria in the process. A decrease in the acid content is desirable since when there is conversion of sugars present in the substrate to acid, the fermentation yield decrease because these carbohydrates are no longer used by the yeast for the ethanol production (Camolez \& Mutton, 2005). Furthermore, lower acid production during the fermentation process is essential for the quality of the sugarcane spirit since these compounds may result in products with an acidic characteristic, consequently reducing their market value (Odello et al., 2009).

As a result of the yeast metabolism, there is the production of ethanol, which is directly influenced by contaminating bacteria since they compete with the yeast for the substrate and can transform sugars into other undesirable compounds such as acids (Camolez \& Mutton, 2005). The addition of antimicrobials to the fermentation process resulted in wines with higher alcohol content compared to those of the control treatment, and the green propolis extract and ampicillin showed the highest mean values (Figure 6).

The use of antimicrobials in alcoholic fermentation resulted in increased alcohol content in the wine produced. The reduction in the number of contaminating microorganisms in the inoculum, induced by the action of biocides, probably caused a decrease in the competition for the substrate between bacteria and yeast, thus leading the conversion of sugars to ethanol. Similar results were found by Camolez \& Mutton (2005) and Basso et al. (2011), who observed a relationship between the increase in the number of bacteria in fermentation and a consequent increase in the acids and a decrease in the ethanol production in wine. It is worth mentioning that the fermentation performed with green propolis extract resulted in an increase in the alcohol content in the wine by $7 \%$, suggesting a better performance of the production process.

\section{Conclusion}

The natural biocides, brown and green propolis, maintaining yeast viability, decrease in the level of acids and a increase in the production process yield.

Based on these results, it is suggested that propolis extracts are assessed in fermentation processes intended for the production of beverages, fermented foods, and biofuels among others.

\section{References}

Afrouzan, H., Amirinia, C., Mirhadi, S. A., Ebadollahi, A., Vaseji, N., \& Tahmasbi, G. (2012). Evaluation of antimicrobial activity of propolis and nanopropolis against Staphylococcus aureus and Candida albicans. African Journal of Microbiology Research, 6(2), 421-425.

Amorim, H. V. (2005). Fermentação alcoólica: ciência e tecnologia. Piracicaba: Fermentec.

Associação Brasileira de Bebidas - ABRABE. (2014). Categorias de mercado. Retrieved from http://www.abrabe.org.br/categorias/.

Basso, L. C., Basso, T. O., \& Rocha, S. N. (2011). Ethanol Production in Brazil: The Industrial Process and Its Impact on Yeast Fermentation. In M. A. S. Bernardes (Ed.), Biofuel Production-Recent Developments and Prospects (pp. 85-100). Rijeka: InTech.

Bhatia, S., Uppal, S. K., Thind, K. S., \& Batta, S. K. (2009). Post harvest quality deterioration in sugarcane under different environmental conditions. Sugar Tech, 11(2), 154-160. Retrieved from http://link. springer.com/article/10.1007\%2Fs12355-009-0023-7. http://dx.doi. org/10.1007/s12355-009-0023-7. 
Burdock, G. A. (1998). Review of the biological properties and toxicity of bee propolis (propolis). Food and chemical toxicology: an international journal published for the British Industrial Biological Research Association, 36(4), 347-363. http://dx.doi.org/10.1016/ S0278-6915(97)00145-2. PMid:9651052

Cabral, I. S. R., Oldoni, T. L. C., Alencar, S. M., Rosalen, P. L., \& Ikegaki, M. (2012). The correlation between the phenolic composition and biological activities of two varieties of Brazilian propolis (G6 and G12). Brazilian Journal of Pharmaceutical Science, 48(3), 557-564. http://dx.doi.org/10.1590/S1984-82502012000300023.

Camolez, M. A., \& Mutton, M. J. R. (2005). Influência de microrganismos contaminantes sobre o processo fermentativo. STAB Açúcar, Álcool e Subprodutos, 23(5), 6-9.

Celestine-Myrtill, A. D. (1990). Influencia de la madurez de la caña em la distribución de azúcares y ácidos organicos en los tallos de la caña de azúcar. Sugar y Azúcar, 85(8), 39-42.

Cigut, T., Polak, T., Gašperlin, L., Raspor, P., \& Jamnik, P. (2011). Antioxidative activity of propolis extract in yeast cells. Journal of Agricultural and Food Chemistry, 59(21), 11449-11455. http:// dx.doi.org/10.1021/jf2022258. PMid:21958212

Food Standards Agency - FSA. (2011). Food sampling by district councils in Northern Ireland - 2011. FSA. Retrieved from http:// www.derrycity.gov.uk/DerryCitySite/files/0e/0eaed70b-0c9f-4acca08d-d8ae3356ec86.pdf.

Isla, M. I., Paredes-Guzman, J. F., Nieva-Moreno, M. I., Koo, H., \& Park, Y. K. (2005). Some chemical composition and biological activity of northern Argentine propolis. Journal of Agricultural and Food Chemistry, 53(4), 1166-1172. http://dx.doi.org/10.1021/jf040130h. PMid:15713035

Kohanski, M. A., Dwyer, D. J., \& Collins, J. J. (2010). How antibiotics kill bacteria: from targets to networks. Nature Reviews. Microbiology, 8(6), 423-435. http://dx.doi.org/10.1038/ nrmicro2333. PMid:20440275

Lavanholi, M. G. D. P. (2008). Qualidade da cana-de-açúcar como matéria-prima para produção de açúcar e álcool. In: L. L. DinardoMiranda, A. C. M. Vasconcelos \& M. G. A. Landell (Eds.), Canade-açúcar (pp. 697-722). Campinas: IAC.

Loureiro, E. M., \& Galbiati, C. (2013). Evaluation of the influence of seasonality and landscape on the physicochemical characteristics of propolis. Food Science and Technology (Campinas.), 33(4), 790-795. http://dx.doi.org/10.1590/S0101-20612013000400027.

Mao, L., Que, F., \& Wang, G. (2006). Sugar metabolism and involvement of enzymes in sugarcane (Saccharum oficinarum L.) stems during storage. Food Chemistry, 98(2), 338-342. http://dx.doi.org/10.1016/j. foodchem.2005.05.076.
Miguel, M. G., Nunes, S., Dandlen, S. A., Cavaco, A. M., \& Antunes, M. D. (2014). Phenols, flavonoids and antioxidant activity of aqueous and methanolic extracts of propolis (Apis mellifera L.) from Algarve, South Portugal. Food Science and Technology (Campinas.), 34(1), 16-23. http://dx.doi.org/10.1590/S0101-20612014000100002.

Montijo, N. A., Silva, A. F., Costa, G. H. G., Ferreira, O. E., \& Mutton, M. J. R. (2014). Yeast CA-11 fermentation in musts treated with brown and green propolis. African Journal of Microbiological Research, 8(39), 3515-3522. http://dx.doi.org/10.5897/AJMR2014.6937.

Odello, L., Braceschi, G. P., Seixas, F. R. F., Silva, A. A., Galinaro, C. A., \& Franco, D. W. (2009). Avaliação sensorial de cachaça. Quimica Nova, 32(7), 1839-1844. http://dx.doi.org/10.1590/S010040422009000700029.

Park, Y. K., Ikegaki, M., Abreu, J. A. S., \& Alcini, N. M. F. (1998). Estudo da preparação dos extratos de própolis e suas aplicações. Ciência e Tecnologia de Alimentos, 18(3), 313-318. http://dx.doi.org/10.1590/ S0101-20611998000300011.

Sforcin, J. M., \& Bankova, V. (2011). Propolis: is there a potential for the development of new drugs? Journal of Ethnopharmacology, 133(2), 253-260. http://dx.doi.org/10.1016/j.jep.2010.10.032. PMid:20970490

Silva, J. F. M., Souza, M. C., Matta, S. R., Andrade, M. R., \& Vidal, F. V. N. (2006). Correlation analysis between phenolic levels of Brazilian propolis extracts and their antimicrobial and antioxidant activities. Food Chemistry, 99(3), 431-435. http://dx.doi.org/10.1016/j. foodchem.2005.07.055.

Silva, L. F. L. F., Bernardino, C. D., Ré, F. E., Furtad, C. H. F., \& Amorim, H. V. (2003). Métodos analíticos para o controle da produção de açúcar e álcool. Piracicaba: Fermentec.

Sobocanec, S., Sverko, V., Balog, T., Sarić, A., Rusak, G., Likić, S., Kusić, B., Katalinić, V., Radić, S., \& Marotti, T. (2006). Oxidant/antioxidant properties of Croatian native propolis. Journal of Agricultural and Food Chemistry, 54(21), 8018-8026. http://dx.doi.org/10.1021/ jf0612023. PMid:17032004

Takaisi-Kikuni, N. B., \& Schilcher, H. (1994). Electron microscopic and microcalorimetric investigations of the possible mechanism of the antibacterial action of a defined propolis provenance. Planta Medica, 60(3), 222-227. http://dx.doi.org/10.1055/s-2006-959463. PMid:8073087

Wu, X., Staggenborg, S., Propheter, J. L., Rooney, W. L., Yu, J., \& Wang, D. (2010). Features of sweet sorghum juice and their performance in ethanol fermentation. Industrial Crops and Products, 31(1), 164-170. http://dx.doi.org/10.1016/j.indcrop.2009.10.006. 